\title{
Gorlin-Goltz Syndrome: The importance of Clinical Investigation and a Multidisciplinary Approach
}

\author{
Síndrome de Gorlin-Goltz: La Importancia de la \\ Investigación Clínica y un Enfoque Multidisciplinario
}

\author{
Andressa Bolognesi Bachesk; Silvia Natália Souza de Peder; \\ Romulo Maciel Lustosa; Lucas Costa Nogueira \& Liogi Iwaki Filho
}

BACHESK, A. B.; PEDER, S. N. S.; LUSTOSA, R. M.; NOGUEIRA, L. C. \& IWAKI FILHO, L. Gorlin-Goltz Syndrome: The importance of clinical investigation and a multidisciplinary approach. Int. J. Odontostomat., 15(1):189-195, 2021.

ABSTRACT: Gorlin-Goltz Syndrome is a genetic disorder characterized by a series of clinical changes, including the presence of multiple odontogenic keratocysts and nevus basal cell carcinomas. As these lesions involve the maxillofacial region and can evolve to severe sequelae, it is essential that the dental surgeon recognize this pathology, in order to promote a correct investigation and early multidisciplinary diagnosis and treatment. The treatment for the cysts varies according to the lesion's characteristics and location, and therefore, the request for complementary exams is essential. According to literature, the approach varies from conservative to more invasive, and several supporting therapies are mentioned. Thus, this article aims to report a case of a young patient diagnosed with Gorlin-Goltz Syndrome by a dental surgeon, who treated conservatively and interdisciplinarly, and obtained a satisfactory result. In addition, it makes a bibliographic review on this genetic condition, elucidating its therapeutic forms.

KEY WORDS: basal cell carcinoma, clinical diagnosis, combined modality therapy, Gorlin-Goltz syndrome, keratocystic odontogenic.

\section{INTRODUCTION}

Gorlin-Goltz Syndrome (GGS), also called Basal Cell Nevus Carcinoma Syndrome, is a genetic disorder of autosomal dominant inheritance (Titinchi et al., 2013; Antonoglou et al. 2014; Khaliq et al., 2016, Nilius et al., 2019). It was first described by Gorlin and Goltz in 1960 (Gorlin \& Goltz, 1960), who characterized it as a triad of multiple nevus basal cell carcinomas, odontogenic keratocysts and bifid ribs (Gorlin \& Goltz; Titinchi et al.; Figueira et al., 2018). It was later modified by Rayner and colleagues, who added other skeletal anomalies, such as cerebral phalanx calcification and palmar lumps (Rayner et al., 1976; Figueira et al.). This disorder can exhibit several clinical signs and symptoms, and in addition to the characteristics already mentioned, other clinical alterations seen are: prognathic jaws, cleft lip and palate, impacted teeth, dental agenesis (Titinchi et al.), epidermoid cysts (Baliga \& Rao, 2010) and other rare abnormalities, such as the development of ovarian fibroids in women (Evans et al., 1993; Shanley et al., 1994; Hasan \& Akintola, 2018) and formation of other neoplasms, such as medulloblastoma and non-Hodgkin's lymphomas (Shanley et al.; Hasan \& Akintola).

The GGS's prevalence varies according to the country where the study was conducted, but it has an average incidence of 1 in 50,000 to 150,000 for the general population (Khaliq et al.; Nilius et al.). The forms of treatment are varied, but they must include the removal of basal cell nevus carcinomas (surgically or not) (Palacios-Álvarez et al., 2018) and keratocysts, ranging from conservative approaches (such as marsupialization / decompression associated or not with enucleation), or radical, with resection (Antonoglou et al.; Khaliq et al.; Ribeiro-Júnior et al., 2017; Hasan \& Akintola). 
Due to the different manifestations and complexity of the syndrome, a multidisciplinary evaluation is necessary to obtain the diagnosis treatment and follow-up of the case properly (PalaciosÁlvarez et al.). Therefore, it is of fundamental importance that different specialists, such as dentists and dermatologists, know the signs and symptoms of the pathology and know how to associate them, in order to obtain a correct and early diagnosis, and consequently, avoid progression of keratocysts and skin lesions, which are at risk of metastases (Figueira et al.). Thus, the work aims is to report a case of a young patient diagnosed with Gorlin-Goltz Syndrome, who treated in a conservative and interdisciplinary way, was successful. In addition, perform a bibliographic review on this genetic condition, elucidating its approach forms.

\section{CASE REPORT}

A 20-year-old female patient, melanoderma, was referred by her orthodontist to the Oral and Maxillofacial Surgery service, for presenting a cyst in anterior mandible region. The clinical examination
(Fig. 1A) revealed a slight asymmetry of mandibular right body, asymptomatic, teeth 32 and 33 in infraocclusion (Fig. 1B) and nodular and brownish lesions in facial (Fig. 1C) and palmar region (Fig. 1D). Radiographically, well-defined radiolucent images were seen in region of teeth 41 to 34 , in retromolar region involving tooth 48 and in right mandibular branch (Fig. 2A). In addition, presence of tooth 13 included. A Cone Beam computed tomography was performed for better evaluation, and a hypodense lesion in lingual region of tooth 46 (Fig. 2B) was observed, in addition to the others mentioned above and already seen by the radiographic exam.

The patient underwent surgery under local anesthesia, with an incisional biopsy of the largest lesion in the posterior region of right mandible, with tooth 48 extraction, and a device installation for lesion decompression of the lesion (Figs. $3 \mathrm{~A}$ and $3 \mathrm{~B}$ ). In addition, enucleation of lesions involving teeth 41 to 34 was associated with peripheral osteotomies (Figs. $3 C$ and $3 D$ ). The materials were sent for histopathological examination, whose diagnosis was Odontogenic Keratocyst. After that, an excisional biopsy of the facial skin lesion was performed (Figs. $4 \mathrm{~A}$ and $4 \mathrm{~B}$ ), whose anatomopathological diagnosis
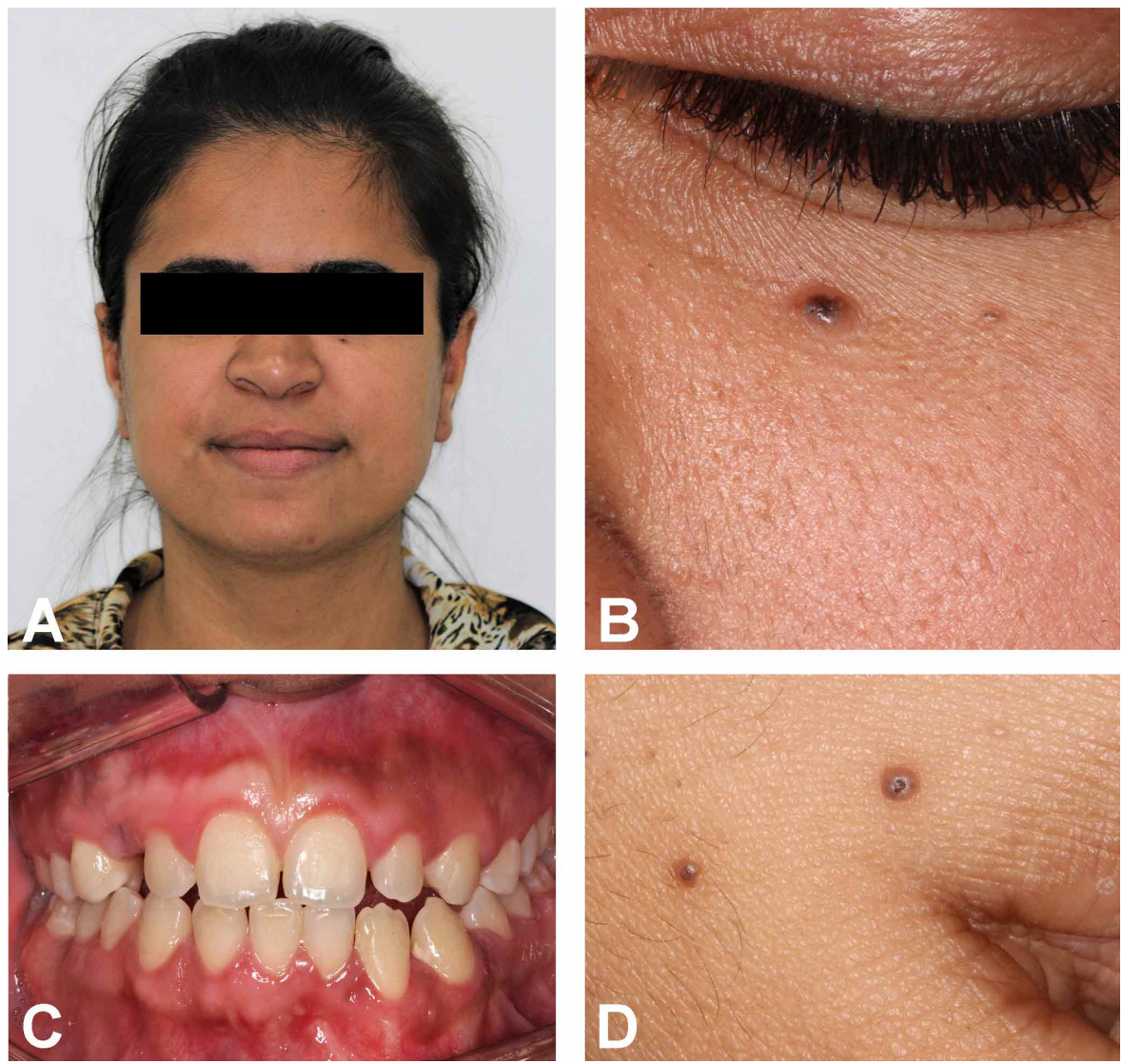

Fig. 1. Clinical images. A) Frontal extraoral photograph; B) Frontal intraoral image of dental occlusion; C) Approximate photograph of skin lesion on the face; D) Approximate photograph showing hand injuries. 

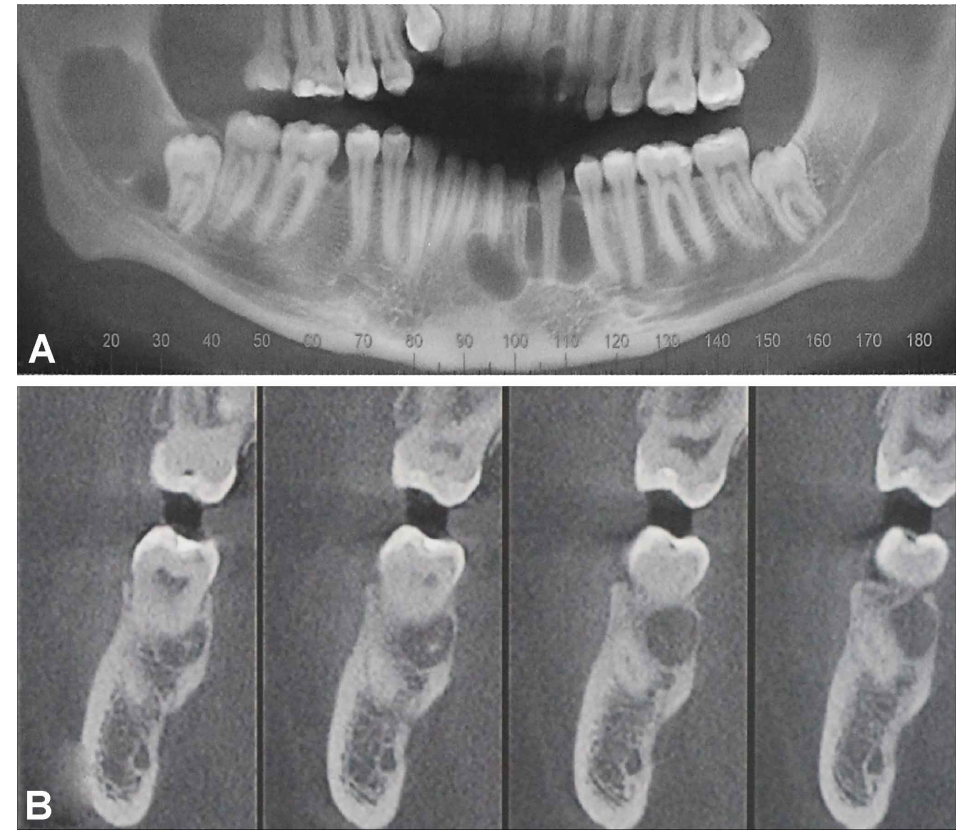

Fig. 2. Imaging exams. A) Panoramic radiograph showing mandible lesions; B) Sequential parasagital sections of lesion involving distal face of tooth 46 .
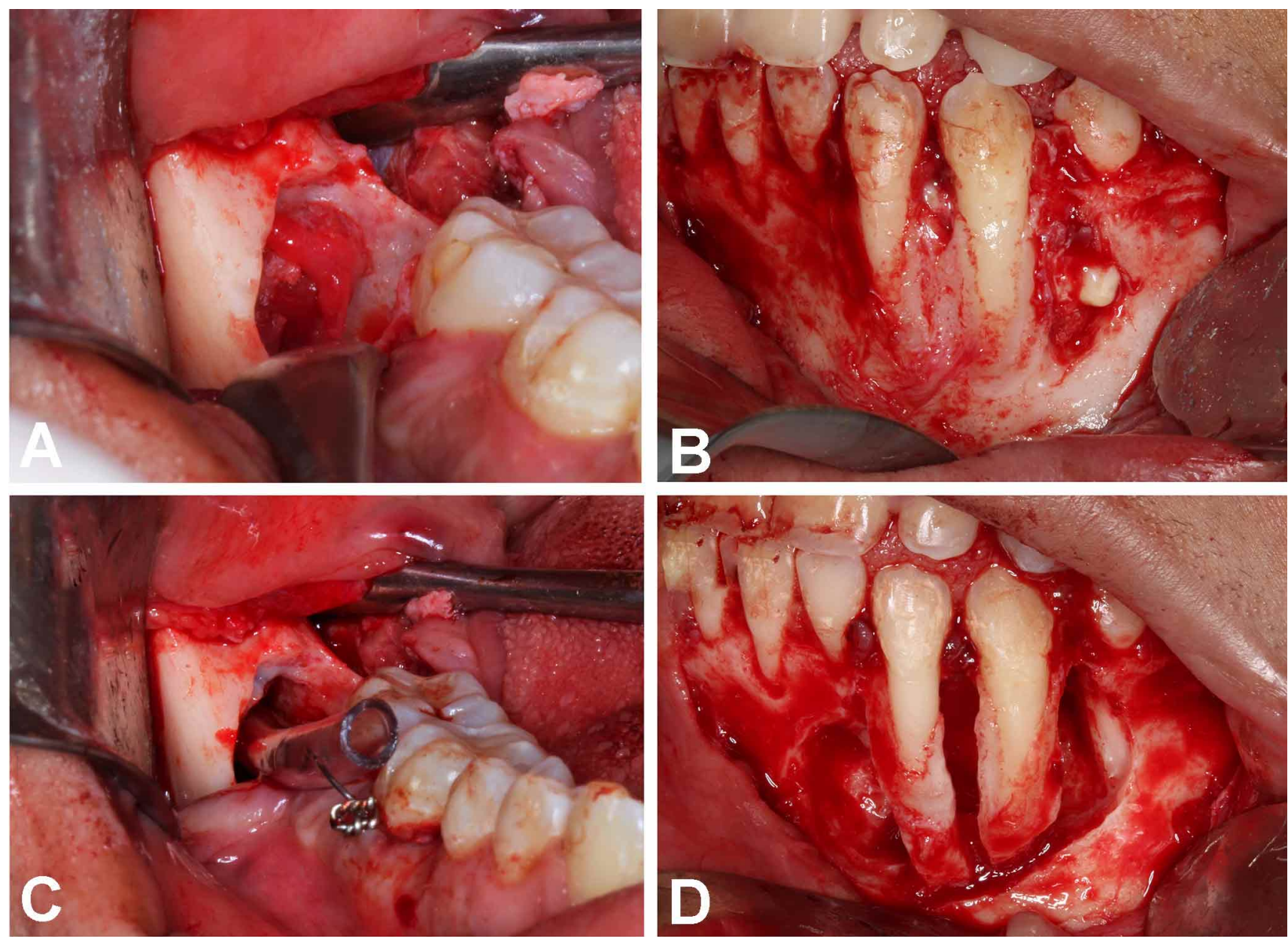

Fig. 3. Transoperative images of first approach. A) Lesion exposure in retromolar region after extraction of tooth 48; B) Device introduction for lesion decompression and stabilization with steel wire; C) Pathology frontal view between teeth 41 to 34 after mucoperiosteal incision and detachment; D) Photograph after lesion removal and performing a peripheral ostectomy. 

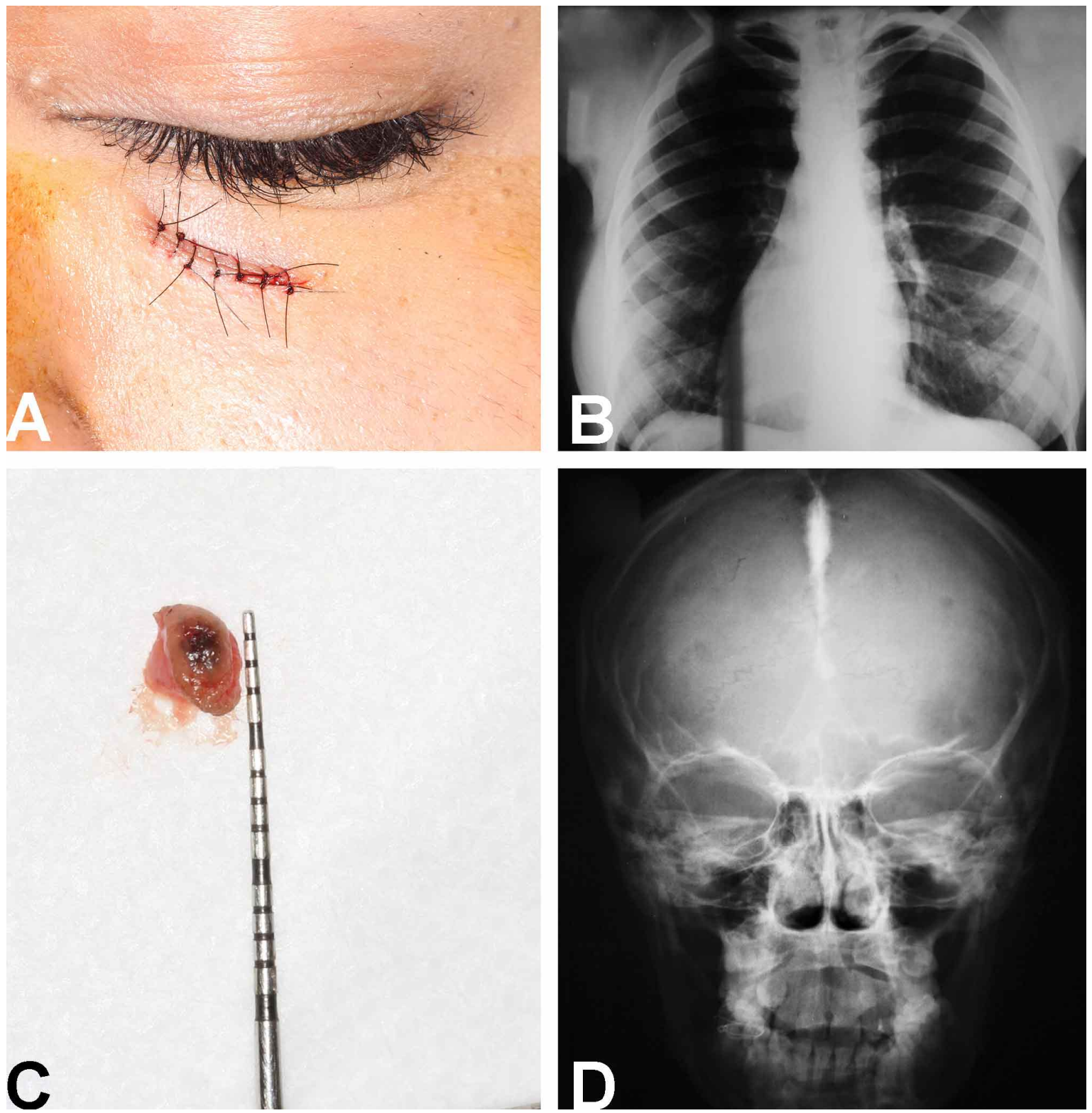

Fig. 4. Complementary exams. A) Sutures after excisional biopsy of skin lesion on the face; B) Surgical specimen removed from the left malar region; C) Chest radiography without changes; D) Skull X-ray showing cerebral sickle calcification.

was Basal Cell Nevoid Carcinoma. Thus, the patient was referred to a dermatologist for evaluation and monitoring of other injuries, whose treatments were also their removal. Next, skull and thorax radiographs were requested, which revealed the presence of cerebral sickle calcification and absence of bifid ribs (Figs. 4C and 4D). After analyzing all these characteristics, the diagnosis of Gorlin-Goltz Syndrome was closed, which, because it is a genetic disorder, proceeded with meticulous investigation of the patient's family history, however, no similar lesions were observed in her relatives.
After 10 months follow-up of decompression surgery, a significant regression of pathology was observed, followed by total enucleation of the lesion of the right mandibular branch and lingual region of tooth 46, associated with peripheral local osteotomy (Fig. 5). The material sent for histopathological examination confirmed the diagnosis of Odontogenic Keratocysts. The patient is in a 36-month postoperative follow-up, with no complaints. Radiographically presents images suggestive of bone neoformation, and no signs of recurrence of cysts or basal cell carcinomas (Fig. 6). 

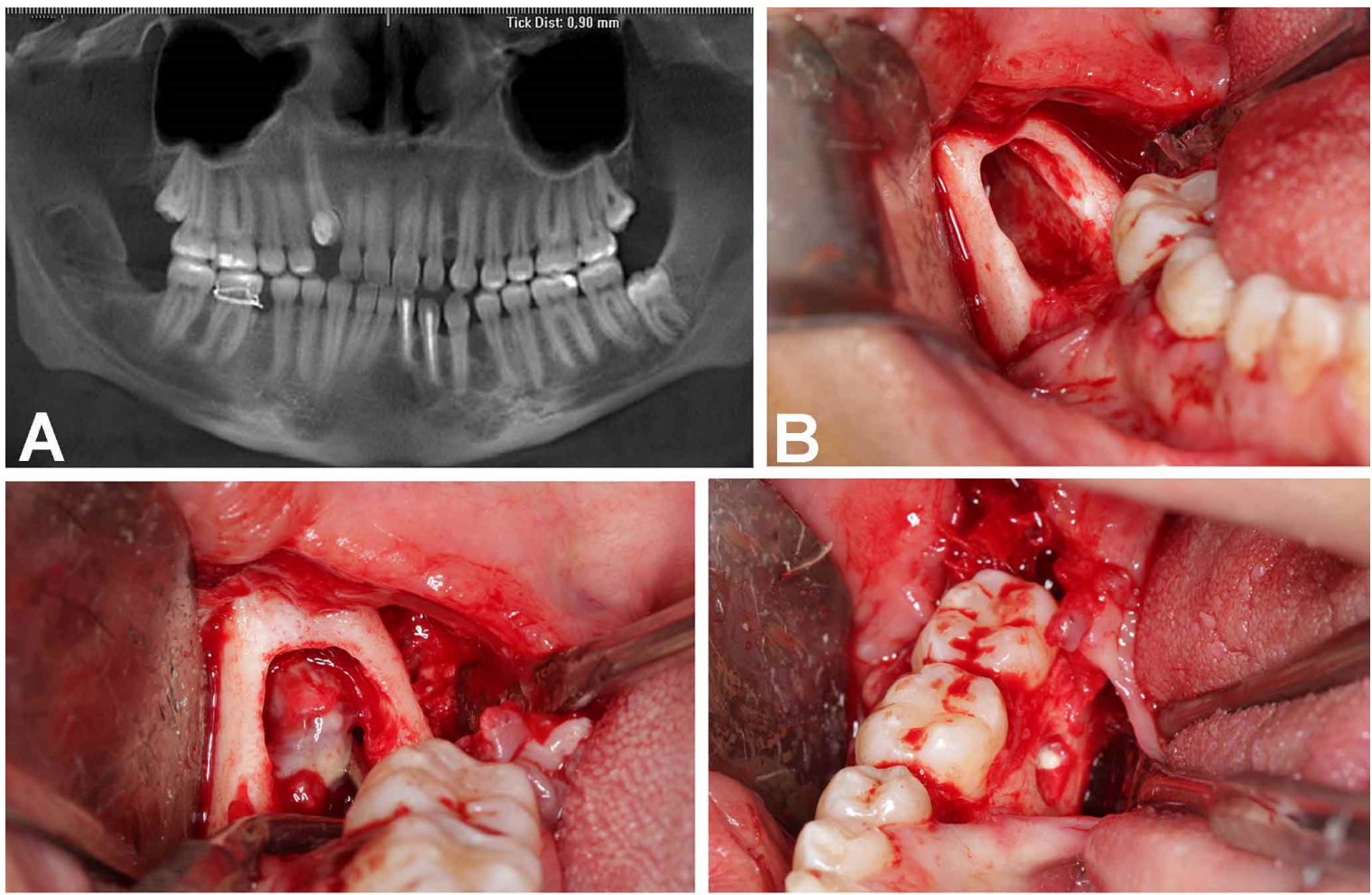

Fig. 5. Postoperative period of 10 months. A) Panoramic follow-up radiography with images suggestive of bone formation and right retromolar lesion reduction; B) Transoperative of the lesion removal; C) Surgical area after total pathology enucleation and peripheral ostectomy; D) Lesion exposure in lingual region of the tooth 46.
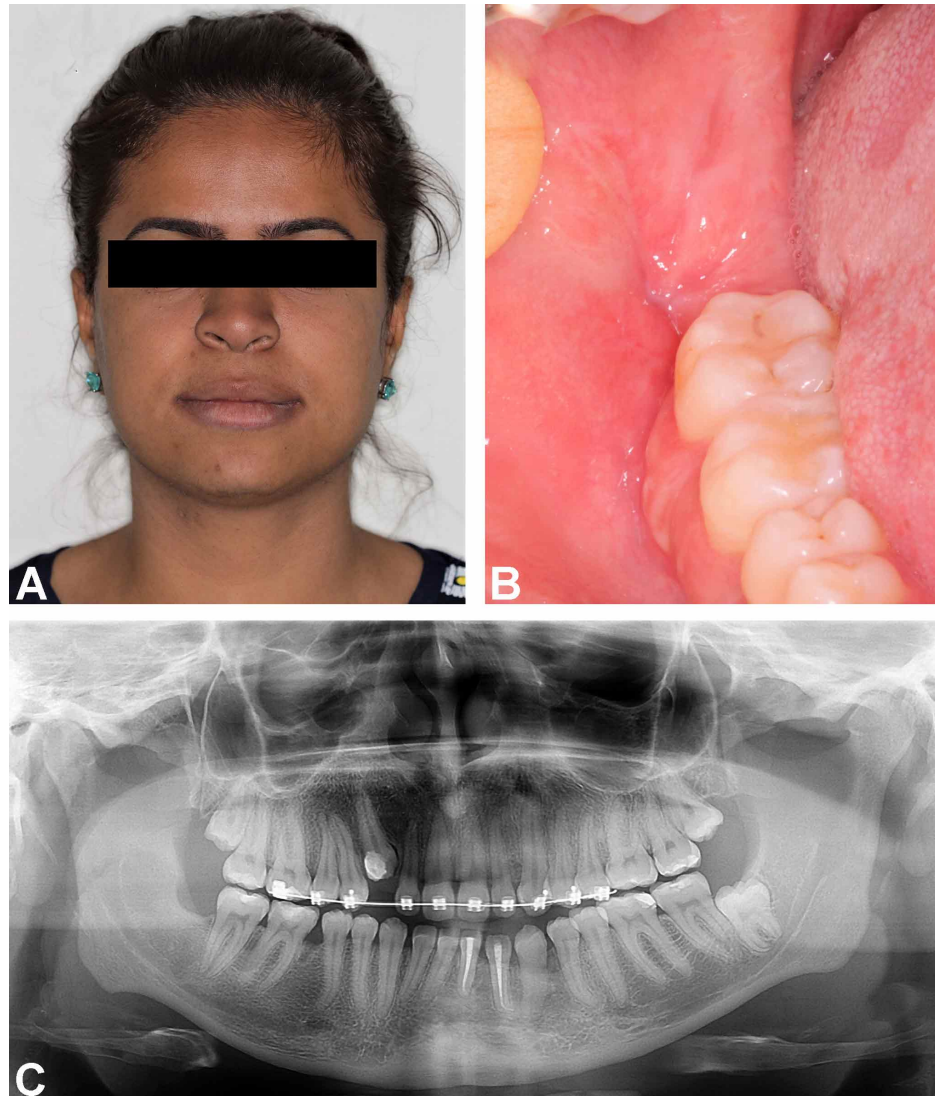

DISCUSSION

Multiple odontogenic keratocysts affect $75-100 \%$ of people with Gorlin-Goltz syndrome, and may be the first sign of this genetic disorder. Although histologically they are similar to nonsyndromic cases, they present a more aggressive behavior (Morgan et al., 2005; Pogrel, 2015; Hasan \& Akintola). Therefore, in multiple odontogenic cysts occurrence, the GGS hypothesis must be investigated (Titinchi et al.; Antonoglou et al.). The occurrence of malignant brain and epithelial tumors are possible complications in cases of late diagnosis (Pogrel; Hasan \& Akintola). Thus, it is essential that the dentist knows how to investigate and obtain an early diagnosis, and consequently, provide an adequate treatment, with better prognosis (Titinchi et al.; Antonoglou et al.; Hasan \& Akintola; Nilius et al.). In our case, the initial

Fig. 6. 3-year follow-up. A) Frontal extraoral image; B) Panoramic follow-up radiography with signs of bone neoformation and without signs of recurrence; C) Intraoral photograph of the healing in right retromolar region. 
manifestations were odontogenic keratocysts and basal cell carcinomas. This reiterates the importance of dental professionals to know the clinical manifestations of conditions that involve not only the oral cavity, but also the whole individual (MacDonald, 2015; Figueira et al.; Hasan \& Akintola).

Skull, face and chest imaging exams are essential for the diagnosis of syndromic changes. Panoramic radiographs are commonly requested in dental routine, and are the main ones mentioned in the diagnosis of jaw injuries (Titinchi et al.; Antonoglou et al.; Hasan \& Akintola; Nilius et al.). However, in syndromic cases, the pathologies are usually multiple, and consequently, difficult to detect accurately in a radiographic examination, which is two-dimensional (Gorlin \& Goltz; Titinchi et al.; Figueira et al.). Therefore, it is essential to request additional exams, such as computed tomography, which is able to define the precise location of the lesion, as well as its dimensions and proximity to noble structures (MacDonald; Ribeiro-Júnior et al.). Thus, facilitating the identification and choice of the appropriate treatment plan for each injury. In the reported case, due to the wide extension of the retromolar lesion, with the possibility of nerve damage and mandibular fragility, we opted for decompression prior to enucleation; and in other minor injuries, direct enucleation associated with complementary therapy. In addition, it is worth mentioning that only by radiographic examination, due to the overlapping of images, it was not possible to visualize the lesion in the lingual region of tooth 46 , and therefore, if tomography had not been performed, this lesion would not have been identified early and would probably evolve.

In 2017, keratocysts returned to category of "developmental odontogenic cysts", stimulating a trend of treatment for these lesions. (Pogrel) As already mentioned, therapies such as decompression, marsupialization and enucleation are described in literature, aiming to reduce the damage to surrounding tissues (Carlson et al., 2015; Pogrel; Ribeiro-Júnior et al.; Hasan \& Akintola). Studies have shown that decompression produces recurrences equivalent, or lower than those of direct enucleation, proving that the procedure does not increase the recurrence rate in medium term, in addition to avoiding damage to noble structures surrounding the injury (Chirapathomsakul et al., 2006; Pogrel; Al-Moraissi et al., 2016). However, due to the increased recurrence risk of keratocysts when they are associated with GGS, supporting methods such as cryotherapy, carnoy solution and peripheral ostectomy are recommended (Shanley et al.; Morgan et al.; Ribeiro-Júnior et al.).
Carnoy's solution is a cauterizing agent composed of acetic acid, chloroform, absolute alcohol and ferric chloride that provides chemical necrosis. Recent reports demonstrate that its use in the pathological region was related to recurrence of 0 to $20 \%$, and has dehiscence, infection, bone sequestrations formation and paresthesia as possible complications (Morgan et al.; Chirapathomsakul et al.; Pogrel; Ribeiro-Júnior et al.). Cryotherapy is a method also described which consists of using liquid nitrogen to promote superficial necrosis of the surgical area. It has been reported with a recurrence rate of $11.5 \%$ and complications such as soft tissue necrosis, wound dehiscence and prolonged recovery (Pogrel). Peripheral ostectomy is based on the removal of 1 to $2 \mathrm{~mm}$ of bone tissue over the entire length of surgical area. It is a simple technique that can be easily performed, has a low complications rate, and has been related to recurrence of 13.1 to $18.2 \%$ (Morgan et al.; Pogrel; Ribeiro-Júnior et al.). Studies have shown that the use of decompression technique, associated with enucleation and peripheral ostectomy, presents satisfactory results, and a work with follow-up from 4 months to 5 years did not present any recurrence case (Pogrel). In the case reported, the complementary treatment chosen was peripheral osteoctomy, due to its simple execution, requiring easily available surgicalinstruments and demonstrating good results regarding the recurrence rate.

It is worth mentioning that long-term follow-up is essential, due to high risk of recurrence and appearance of new keratocysts (Evans et al.; Pogrel). The request for an annual panoramic radiograph in syndromic patients should be part of the assistance protocol (Rayner et al.; Baliga \& Rao; Figueira et al.). Therefore, semiannual supervision for the first five years and annually thereafter is of great importance for patients affected by GGS (Rayner et al.; Baliga \& Rao; Figueira et al.). In our case, the patient is being followed up for 3 years, with no evidence of recurrence or new lesions appearance.

\section{CONCLUSION}

The Gorlin-Goltz Syndrome diagnosis is directly related to treatment to be instituted and the case prognosis, and therefore, it is essential that it is obtained early. This disorder can be identified through routine radiographic examinations and assessments of the patient's systemic manifestations. Thus, it is necessary that dental surgeons and doctors recognize the 
manifestations of this disorder and act in a multidisciplinary way to accelerate the process of diagnosis and treatment, paying attention to general signs and symptoms, and not just focused on their practice area.

The use of computed tomography is important for the detection and precise location of the lesions, and its evaluation can guide the treatment to be instituted. Decompression therapy for large lesions associated with enucleation and peripheral ostectomy is a conservative and simple treatment that has shown adequate results. Follow-up is essential for the early detection of possible recurrences. In addition, due to its hereditary component, it is essential that the investigation occurs not only in the patient, but also in his/her family.

BACHESK, A. B.; PEDER, S. N. S.; LUSTOSA, R. M.; NOGUEIRA, L. C. \& IWAKI FILHO, L. Síndrome de Gorlin-Goltz: la importancia de la investigación clínica y un enfoque multidisciplinario. Int. J. Odontostomat., 15(1):189-195, 2021.

RESUMEN: El síndrome de Gorlin-Goltz es un trastorno genético caracterizado por una serie de cambios clínicos, que incluyen la presencia de múltiples queratoquistes odontogénicos y nevus carcinomas basocelulares. Como estas lesiones involucran la región maxilofacial y pueden evolucionar a secuelas severas, es esencial que el cirujano oral conozca esta patología para realizar una investigación correcta y un diagnóstico y tratamiento multidisciplinario temprano. El plan de tratamiento para los quistes varía de acuerdo con las características y la ubicación de la lesión y, por lo tanto, la solicitud de exámenes complementarios es esencial. Según la literatura, el enfoque varía de conservador a más invasivo, y se mencionan varias terapias de apoyo. Por lo tanto, este artículo tiene como objetivo informar un caso de un paciente joven diagnosticado con el síndrome de Gorlin-Goltz por un cirujano dentista, que trató de forma conservadora e interdisciplinaria, y obtuvo un resultado satisfactorio. Además, realiza una revisión bibliográfica sobre esta condición genética, aclarando sus formas terapéuticas.

PALABRAS CLAVE: carcinoma basocelular, diagnóstico clínico, terapia de modalidad combinada, síndrome de Gorlin-Goltz, queratoquiste odontógeno.

\section{REFERENCES}

Al-Moraissi, E. A.; Pogrel, M. A. \& Ellis 3rd, E. Enucleation with or without adjuvant therapy versus marsupialization with or without secondary enucleation in the treatment of keratocystic odontogenic tumors: A systematic review and meta-analysis. J. Craniomaxillofac. Surg., 44(9):1395-403, 2016.

Antonoglou, G. N.; Sándor, G. K.; Koidou, V. P. \& Papageorgiou, S. N. Non-syndromic and syndromic keratocystic odontogenic tumors: systematic review and meta-analysis of recurrences. J. Craniomaxillofac. Surg., 42(7):e364-71, 2014.
Baliga, S. D. \& Rao, S. S. Nevoid-basal cell carcinoma syndrome: a case report and overview on diagnosis and management. $J$. Maxillofac. Oral Surg., 9(1):82-6, 2010.

Carlson, E. R.; Oreadi, D. \& McCoy, J. M. Nevoid basal cell carcinoma syndrome and the keratocystic odontogenic tumor. J. Oral Maxillofac. Surg., 73(12 Suppl.):S77-86, 2015.

Chirapathomsakul, D.; Sastravaha, P. \& Jansisyanont, P. A review of odontogenic keratocysts and the behavior of recurrences. Oral Surg. Oral Med. Oral Pathol. Oral Radiol. Endod., 101(1):5-9, 2006.

Evans, D. G.; Ladusans, E. J.; Rimmer, S.; Burnell, L. D.; Thakker, N. \& Farndon, P. A. Complications of the naevoid basal cell carcinoma syndrome: results of a population based study. J. Med. Genet., 30(6):460-4, 1993.

Figueira, J. A.; Batista, F. R. S.; Rosso, K.; Veltrini, V. C. \& Pavan, A. J. Delayed diagnosis of Gorlin-Goltz Syndrome: the importance of the multidisciplinary approach. J. Craniofac. Surg., 29(6):e530-1, 2018.

Gorlin, R. J. \& Goltz, R. W. Multiple nevoid basal-cell epithelioma, jaw cysts and bifid rib. A syndrome. New Engl. J. Med., 262:908-12, 1960.

Hasan, A. \& Akintola, D. An update of Gorlin-Goltz syndrome. Prim. Dent. J., 7(3):38-41, 2018

Khaliq, M. I. U.; Shah, A. A.; Ahmad, I.; Hasan, S.; Jangam, S. S.; Farah \& Anwar. Keratocystic odontogenic tumors related to Gorlin-Goltz syndrome: A clinicopathological study. J. Oral Biol. Craniofac. Res., 6(2):93-100, 2016.

MacDonald, D. S. A systematic review of the literature of nevoid basal cell carcinoma syndrome affecting East Asians and North Europeans. Oral Surg. Oral Med. Oral Pathol. Oral Radiol., 120(3):396-407, 2015.

Morgan, T. A.; Burton, C. C. \& Qian, F. A retrospective review of treatment of the odontogenic keratocyst. J. Oral Maxillofac. Surg., 63(5):6359, 2005.

Nilius, M.; Kohlhase, J.; Lorenzen, J.; Lauer, G. \& Schulz, M. C. Multidisciplinary oral rehabilitation of an adolescent suffering from juvenile Gorlin-Goltz syndrome - a case report. Head Face Med., 15(1):5, 2019.

Palacios-Álvarez, I.; González-Sarmiento, R. \& Fernández-López, E. Gorlin syndrome. Actas Dermosifiliogr., 109(3):207-17, 2018.

Pogrel, M. A. The keratocystic odontogenic tumour (KCOT)--an odyssey. Int. J. Oral Maxillofac. Surg., 44(12):1565-8, 2015.

Rayner, C. R.; Torres, J. F. \& Wilson, J. S. What is Gorlin's syndrome? The diagnosis and management of the basal cell naevus syndrome, based on a study of thirty-seven patients. Br. J. Plast. Surg., 30(1):627, 1976.

Ribeiro-Júnior, O.; Borba, A. M.; Alves, C. A. F.; de Gouveia, M. M.; Deboni, M. C. Z. \& Naclério-Homem, M. G. Reclassification and treatment of odontogenic keratocysts: A cohort study. Braz. Oral Res., 31:e98, 2017.

Shanley, S.; Ratcliffe, J.; Hockey, A.; Haan, E.; Oley, C.; Ravine, D.; Martin, N.; Wicking, C. \& Chenevix-Trench, G. Nevoid basal cell carcinoma syndrome: review of 118 affected individuals. Am. J. Med. Genet., 50(3):282-90, 1994

Titinchi, F.; Nortje, C. J.; Parker, M. E. \& van Rensburg, L. J. Nevoid basal cell carcinoma syndrome: a 40-year study in the South African population. J. Oral Pathol. Med., 42(2):162-5, 2013.

Corresponding author:

Andressa Bolognesi Bachesk

Mandacaru Avenue, 1550

Zip code 87080-000

Maringá- PR

BRAZIL

Email: andressabachesk@gmail.com 